\title{
Experience Curve Development and Cost Reduction Disaggregation for Fuel Cell Markets in Japan and the US
}

\author{
Max Wei, Sarah. J. Smith, Michael D.Sohn \\ Lawrence Berkeley National Laboratory \\ December 28, 2016
}

\section{Abstract:}

Technology learning rates can be dynamic quantities as a technology moves from early development to piloting and from low volume manufacturing to high volume manufacturing. This work describes a generalizable technology analysis approach for disaggregating observed technology cost reductions and presents results of this approach for one specific case study (micro-combined heat and power fuel cell systems in Japan). We build upon earlier reports that combine discussion of fuel cell experience curves and qualitative discussion of cost components by providing greater detail on the contributing mechanisms to observed cost reductions, which were not quantified in earlier reports. Greater standardization is added to the analysis approach, which can be applied to other technologies. This paper thus provides a key linkage that has been missing from earlier literature on energy-related technologies by integrating the output of earlier manufacturing cost studies with observed learning rates to quantitatively estimate the different components of cost reduction including economies of scale and cost reductions due to product performance and product design improvements. This work also provides updated fuel cell technology price versus volume trends from the California Self-Generation Incentive Program, including extensive data for solid-oxide fuel cells (SOFC) reported here for the first time. The Japanese micro-CHP market is found to have a learning rate of $18 \%$ from 2005-2015, while larger SOFC fuel cell systems (200kW and above) in the California market are found to have a flat (near-zero) learning rate, and these are attributed to a combination of exogenous, market, and policy factors.

Keywords: PEM fuel cells, solid oxide fuel cells, combined heat and power systems, technology learning rates, experience curves, technology deployment programs 


\section{Introduction - Fuel Cells in Stationary Applications}

Fuel cells are both a longstanding and emerging technology for stationary and transportation

31 applications, and their future use may be critical for the deep decarbonization of global energy systems.

32 For example fuel cell (FC) systems are being considered for a range of stationary and specialty transport

33 applications due to their ability to provide reliable power with cleaner direct emissions profiles than fossil

34 fuel combustion-based systems. Existing and emerging applications include primary and backup power,

35 combined heat and power (CHP), materials handling equipment such as forklifts and airport handling

36 equipment, and auxiliary power applications such as auxiliary power units in diesel truck cabins.

37 As a chemical energy conversion process, fuel cells have intrinsically higher efficiency and much lower

38 criteria pollutant emissions than coal or gas combustion-based plants [1]. Stationary applications are also

39 less constrained to the weight and size limitations of vehicles. In addition, fuel cells can serve as a reliable

40 source of base load power in comparison to intermittent wind or solar photovoltaic supply sources. If fuel

41 cells become widely available they could help to displace coal plants and improve public health outcomes

42 due to the elimination of coal-fired air pollutants such as fine particulate matter, and they might also

43 displace nuclear plants and avert the disposal issues associated with nuclear waste. Fuel cell systems also

44 can qualify as distributed generation systems and as power supply sources close to load, they may not

45 trigger transmission line construction or line losses.

Stationary fuel cell systems are not deployed in high volumes today due to a number of reasons

that limit the market adoption of new technologies. In particular, market adoption of FC systems is constrained by their high initial capital costs and durability issues [2]. If FC lifetime is not proven in

49 demonstration programs, for example, potential owners such as commercial building operators are not

50 likely to invest in them. Similarly, if FC equipment is demonstrated to have equivalent to better lifetime

51 than incumbent technology, but with much higher capital cost, market adoption will be low in the absence

52 of other incentive programs.

53 The ultimate vision of a hydrogen economy -- where $\mathrm{H}_{2}$ is produced renewably and fed into a fuel

54 cell which produces no emissions -- is constrained by the above fuel cell system cost and reliability 
constraints, the cost and efficiency issues of generating renewable hydrogen, and the cost and infrastructure of storing and transporting hydrogen with the equivalent availability and convenience of existing fuel or energy carrier types. Currently, $\mathrm{H}_{2}$ is predominantly produced from converting natural gas to $\mathrm{H}_{2}$ using steam methane reforming, a process which results in greenhouse gas emissions.

The U.S. Department of Energy (DOE) has historically invested in fuel cell technology development and deployment of FC systems (e.g. roughly \$95 million in fiscal year 2015), with recent reported success in the material handling and backup power segments, and there continues to be support

62 from the federal government in terms of federal tax credits for stationary FC power systems. ${ }^{1}$ At the state

63 level, there are various state incentive programs such as the Self-Generation Incentive Program in

64 California (SGIP) which provides performance-based incentives for facilities that install qualifying

65 distributed power and heating technologies such as fuel cells. ${ }^{2}$ Internationally, fuel cell development is progressing in many countries including Japan, Europe, and Australia. International deployment programs

67 include renewable portfolio standards in South Korea that include fuel cells with renewable biogas and CHP targets in Germany that include fuel cell CHP systems. ${ }^{3}$ The nuclear accident at Fukushima in Japan has increased concerns about nuclear power plant safety and long term viability and is another driving force for the greater deployment of non-nuclear low carbon energy sources and low-carbon distributed 71 generation. area of research for material development and characterization, fuel cell stack manufacturing processes,

74 stack and system operation and characterization, and management of reactants and heat [3-6]. Both PEM

75 fuel cells and other types of fuel cells have been an active area of development for a wide set of diverse 76 applications from heat and power in residential applications [7] to bus transportation [8] and waste water 77 treatment [9].

\footnotetext{
${ }^{1}$ http://energy.gov/savings/business-energy-investment-tax-credit-itc, accessed 10 March 2015.

2 http://www.cpuc.ca.gov/sgip/, accessed 22 December 2016.

${ }^{3}$ See for example, http://www.fuelcellenergy.com/applications/financial-incentives/international-incentives/, accessed 1 June 2015.
} 
Globally, fuel cell shipments have grown at $15 \%$ by MW and $37 \%$ by unit per year from 2009-2014, led by the stationary sector which shipped over $80 \%$ of the units in 2014 [10]. About two-thirds of MW shipped in 2014 was in Asia, led by Japan, with about 30\% of total MW shipped to North America. Solid oxide fuel cell (SOFC) MW shipments have increased from 1.1 MW in 2009 to $32.3 \mathrm{MW}$ in 2014 with molten-carbonate fuel cells (MCFC) growing from $18 \mathrm{MW}$ to $70 \mathrm{MW}$. Currently, the transportation market is a very small fraction of the overall fuel cell market, but that may shift if fuel cell vehicles continue to be introduced and are more widely adopted. Toyota introduced a fuel cell passenger vehicle in November 2014 and Honda in March 2016. forecasters who seek to track and/or accelerate their market adoption is the ability to forecast market costs of the fuel cells as technology innovations are incorporated into market products. Specifically, there is a need to estimate technology learning rates, which are rates of cost reduction versus production volume. Learning rates can dynamic quantities and should be updated on a periodic basis to understand price

91 reduction trends and the potential impacts of deployment programs, technology development, exogenous

92 factors, and other factors. For example, to our knowledge, a price versus cumulative volume trend for the 93 SOFC fuel cell market in California under the state's Self-Generation Incentive Program (SGIP) has not 94 been published. programs: (1) the micro-combined heat and power (CHP) program in Japan, and (2) for SOFC fuel cell 97 systems in California, the latter for the first time. These two examples have a relatively broad set of 98 historical market data and thus provide an informative and international comparison of distinct fuel cell 99 technologies and government deployment programs. This report thus provides a critical update on fuel 100 cell costs from an experience curve perspective and disaggregates observed cost reduction components 101 using a direct manufacturing cost model.

102 A generalized procedure for disaggregating experience-curve cost-reduction components is 103 described and applied to the Japanese fuel cell micro-CHP market. This approach utilizes a vendor-level 
manufacturing cost model and known features of the Japanese fuel cell market are synthesized to estimate system cost reductions due to economies of scale, product performance improvement, and product design improvements. This approach provides an explicit decomposition of observed fuel cell system cost

107 reduction elements for the first time.

108 We describe the empirically-observed learning rates as a function of production maturity and 109 compare the policy and external environments for both cases. We discuss general observations and

110 pertinent policy lessons from the two case studies along with how the cost reduction disaggregation

111 analysis can be generalized to other technologies. We explore the differences in the technology

112 development ecosystem and market conditions that may have contributed to the observed differences in

113 cost reduction and draw policy observations for the market adoption of future fuel cell technologies.

114 This work highlights the critical importance of updating experience curves over time since with

115 changes in technology, regulations, and international market conditions, changes in the slope of the

116 experience curve can be observed. The Japanese micro-CHP market is found to have a learning rate of

$11718 \%$ from 2005-2015, while larger SOFC fuel cell systems (200kW and above) in the California market

118 are found to have a flat (near-zero) learning rate, and these are attributed to a combination of exogenous,

119 market, and policy factors described below. The technical and policy contributions of this paper are the

120 first comparative experience curve analysis of past fuel cell technologies in two distinct markets, and the

121 first quantitative comparison of a detailed cost model of fuel cell systems with actual market data. The

122 resulting approach is applicable to analyzing other fuel cell markets and other energy-related

123 technologies, and highlights the data needed for cost modeling and quantitative assessment of key cost

124 reduction components. can occur, a concept originating from observations that manufacturing processes improve as production 128 increases [11]. This has important implications for understanding past technology developments and 129 program benefits, as well as forecasting technology growth for policy planning and scenario modeling. 
130 Thus as federal and state governments make investment and policy decision in energy technology

131 research, development, and deployment, the learning rate of FC systems and technologies are important

132 as a factor for projecting future technology costs and technology adoption. (Deployment programs here

133 refer to a broad range of programs, from education and awareness programs, to financial incentive

134 programs, to design competitions, to federal testing and performance standards). For example, assuming

135 a certain learning rate for the future defines the market adoption that is needed to meet a certain cost

136 target and an appropriate incentive structure. Making an erroneous learning rate assumption that is too

137 conservative (or too aggressive) could lead to an inefficient policy that is too generous (or insufficient) to

138 meet the policy target.

139 Experience curves are the most common framework for assessing technology learning and cost

140 reduction with increasing production volume [12]. These curves are found, empirically, to follow a power

141 law as shown in Equation 1, with the rate of cost reduction a power law function of cumulative

142 production volume.

$$
\text { Equation 1. } \quad C\left(t_{2}\right) / C\left(t_{1}\right)=\left(V\left(t_{2}\right) / V\left(t_{1}\right)\right)^{-b}
$$

$$
\text { Where: } \quad C\left(t_{2}\right)=\text { cost at time } t_{2}
$$$$
\mathrm{C}\left(\mathrm{t}_{1}\right)=\text { cost at time } \mathrm{t}_{1}
$$

150 learning rate $\left(\mathrm{LR}=1-2^{-\mathrm{b}}\right)$, while the fraction of initial cost remaining after every doubling of production is

151 defined as the progress ratio $(\mathrm{PR}=1-\mathrm{LR})$. Learning rates are important parameters and in many cases are

152 taken as exogenous assumptions in future energy system planning and scenario analysis [13-14].

153 Learning rates in this case are critical input parameters in regards to future technology costs and market 154 adoption potential. 

experience curves, which relate cumulative production to overall cost or price (although the terms

157 "learning curve" and "experience curve" are often used interchangeably). Therefore, learning curves 158 reflect short-run learning-by-doing, while experience curves incorporate a much broader set of cost 159 components [15]. Shifts in production cost may be reflected in the experience curve by a change in the 160 learning rate, or slope of the curve. Similarly, we refer to a "learning rate" here as defined above, 161 although the term "experience rate" may be more accurate.

Market prices are often utilized as a proxy for a product's manufactured costs since market prices 163 are more directly observable than manufacturing costs. However, prices can mask the cost structure of a 164 product and introduce uncertainties in the product's technology learning due to pricing and market 165 effects. Despite these caveats, market prices are often used for experience curve analyses.

\subsection{Literature Review - Non-Fuel Cell Energy-related Technologies}

Forty-one non-fuel cell studies were reviewed from the recent literature since 2012 to assess the state-of-the art analysis and uniqueness of this work. These studies can be classified in three general categories: (1) critiques, compilations, and calculations of past learning rates [16-31]; (2) "top-down"

171 studies that typically use previously estimated learning rates as an input into forecasting models for future

172 learning rates and costs [32-48]; and (3) "bottom-up" studies that attempt to explain the components of

173 observed learning rates through a consideration of factors including learning-by-doing, technology R\&D,

174 manufacturing, labor, and material costs, and other exogenous factors [49-56]. We focus on the third

175 category here since it is most relevant. For example, earlier top-down studies have estimated and derived

176 learning rates in power plant component costs from empirical observations to estimate future cost

177 reductions, but this category of studies does not derive component costs from bottom up manufacturing

178 considerations $[34,48]$. We find a gap in the literature in that none of the previous papers utilize a

179 "bottom-up" direct manufacturing cost model to estimate cost reduction components from product 180 performance, product design improvements, and economies of scale. This work is thus unique in that it 
utilizes a well-documented direct manufacturing cost model to estimate cost reduction components of a

182 well-defined experience curve (the Japanese micro-CHP fuel cell market) for the first time. Other studies

183 contain elements of this approach but we believe the linkages made here are more direct and more

184 transparent than earlier reports. Note that other higher-level modeling approaches consider somewhat

185 abstracted concepts of "learning-by-doing" and "learning-by-searching" and we provide more explicit

186 linkages of observed cost reductions to actual product-related performance data and product attributes.

187 Qiu and Anadon [49] disaggregates the learning rate in the Chinese wind turbine market from

188 2003-2007 and into two key parts: learning-by-doing and learning-by-searching (e.g., technology R\&D)

189 utilizing a "Cobb-Douglas production model coupled with a bottom up engineering model." Unlike this

190 paper, the paper does not quantify other cost reduction components such as economies of scale with a

191 manufacturing cost model and does not discuss balance of plant costs.

The most widely cited recent papers are papers are two on solar PV. Bazilian et al. [50] provides

193 some disaggregation of observed cost reductions (for example in the price of inputs polycrystalline

194 silicon) but the approach is qualitative and illustrative rather than an explicit linkage of a manufacturing

195 cost model to falling costs and economies of scale. Some manufacturing costs are provided but are not

196 tied to production volume and do not include balance of system costs. Goodrich et al. [51] provides an

197 assessment of overall solar PV costs in 2010 in the residential, commercial, and utility market segments

198 by compiling module, bill-of-material costs, installation and mark-ups, and also projects the cost

199 reduction potential in 2020 for each market. The 2020 values take module prices as an input and the

200 study does not compare cost component breakdowns to observed learning rates.

Another solar PV paper (Candalise et al. [52]) “describes, and considers the causes of, recent

202 changes in PV costs and prices at module and system level" but is largely qualitatively descriptive and

203 does not utilize a manufacturing cost model. The authors note that "overall, it is not straightforward to

204 fully disentangle module price reductions due to reduced production costs related to device and

205 production processes improvements and economies of scale along the PV module value chain." Gan et al. 
[53] estimated PV module cost "using the learning curve concept" and integrated silicon prices as an additional factor to examine its role in production cost changes.

Some studies consider detailed production costs and future cost reduction opportunities in established areas such as wood production and petroleum production but without presenting a well-

210 defined historical experience curve for comparison (deWit et al. [54], Aguilera [55]); and others provide

211 detailed techno-economic performance and cost reduction potential for emerging technologies such as

212 synthetic natural gas production and power cogeneration with carbon capture and storage (Li et al.[56])

213 but again with insufficient industry activity to generate an experience curve.

\section{1.3 Literature Review - Fuel Cell Experience Curves}

215 While several papers have reported fuel cell experience curves, experience curves with actual

216 market data is more limited and published experience curves with recent data are even more limited.

217 Historic examples of fuel cell experience curves have limited production volume and time series data.

218 Rivera-Tinoco et al. [57] find early commercial learning rate for solid oxide fuel cells (SOFC) slowing

219 down to a learning rate of 5\% in the early commercial phase from an apparent $44 \%$ learning rate in the

220 pilot phase. However, no published reports for recent SOFC experience curves in the California fuel cell

221 market were found. Schoots et al. [58] find that proton exchange membrane fuel cells (PEM) in

222 transportation have a learning rate of $21 \%$ for a global cumulative capacity of $100 \mathrm{MW}$, but this only

223 represents on the order of a few thousand vehicles (e.g., $100 \mathrm{~kW} * 1000$ units $=100 \mathrm{MW}$ for Toyota

224 Mirai fuel cell vehicle at $114 \mathrm{~kW}$ peak power). This paper cites eight references for PEM learning

225 curves, but of the eight, one is very old (from 1995), and six of the eight are manufacturing cost modeling

226 papers and not actual data. Thus the actual data for this technology is extremely limited. Mayer et al.

227 [59] uses a two-factor experience curve approach to project 2020 costs for PEM fuel cells and lithium-ion

228 batteries. This work relies on extensive patent analysis and is not a bottom up manufacturing cost

229 modeling approach.

230 Three recent reports (Staffell and Green [60], Dodds et al. [61], and Harikishan et al. [62])

231 present data for the learning rate of the Japanese and Korean micro-CHP market from initial introduction 
to early commercialization with a learning rate of about $19 \%$ in the pilot phase of development slowing to $13 \%$ in the commercial phase in Japan. Staffell and Green provide a general discussion of manufacturing

234 cost considerations based on James et al. [63] and attribute a slowing in the learning rate to the

235 observation that balance of plant costs dominate overall system costs as manufacturing volumes increase,

236 that those component costs have a slower cost reduction than the fuel cell stack which makes up a larger

237 fraction of costs at low volume. Dodds et al. provide an overall market review of hydrogen fuel cell

238 systems for heating and discussion of micro-CHP systems market trends in Japan and Korea. Hiroshi

239 [64] provides a more updated technical analysis of the Japanese micro-CHP technology including detailed

240 thermodynamic analysis and power and heat output shapes of representative systems.as well an

241 assessment of the long term competitive price target and $\mathrm{CO}_{2}$ savings for these systems in Japan. Neij

$242[65]$ notes that many earlier fuel cell studies utilize experience curves for cost analysis, but most assume a

243 learning rate rather than presenting a historical time series of price data (e.g., [66] and [67]).

244 Thus an updated look at fuel cell experience curves is essential to provide the latest assessment of fuel

245 cell cost trends and to provide more detailed analysis of observed cost reductions.

\section{Japan's Micro-CHP program and the California SGIP Program}

In this section we highlight some of the key similarities and differences in the two regions' fuel

248 cell programs. We discuss the implications of these findings together with the empirically derived cost

249 reduction results in the Discussion section below.

Both case studies produce systems with fuel cells as an energy provider and in both cases there

251 were initially generous subsidies from the government, which are now declining. Comparison of the two

252 programs shows marked differences in many areas: markets, energy prices, development models, and

253 environmental and exogenous factors. The role and stated goals of the government are more directed and

254 specified in Japan with a target annual volume in 2020 and 2030; whereas the U.S. policy is to provide

255 incentives to offset higher capital costs without a policy mandate to install a specified target number of

256 units nationwide by a certain date. 
Table 1. Japan's Micro-CHP program and the California SGIP

\begin{tabular}{|c|c|c|}
\hline Case & Japan Ene-farm & California SGIP \\
\hline Companies & Toshiba, Panasonic, AISIN & $\begin{array}{l}\text { Bloom Energy, Fuel Cell Energy, } \\
\text { Doosan (formerly ClearEdge } \\
\text { Power/UTC Power) }\end{array}$ \\
\hline Company Type & Large diverse & $\begin{array}{l}\text { Dedicated FC (BE and FCE), Large } \\
\text { diverse (Doosan) }\end{array}$ \\
\hline System Application & Residential micro-CHP & Commercial power \\
\hline System Size & $0.7-1 \mathrm{~kW}$ & $200-500 \mathrm{~kW}$ \\
\hline $\begin{array}{l}\text { Incumbent Energy } \\
\text { Source Costs }\end{array}$ & $\begin{array}{l}\$ 0.26 / \mathrm{kWh} \text {, Japan residential } \\
\$ 1.08 / \text { therm LNG import price }\end{array}$ & $\begin{array}{l}\$ 0.11 / \mathrm{kWh} \text {, U.S. commercial } \\
\$ 0.447 / \text { therm NG city gate price }\end{array}$ \\
\hline Incentive Structure & $\begin{array}{l}\text { Decreasing over time ( } \$ 12000 \text { per } \\
\text { system to } \$ 3300 \text { from } 2009-2014)\end{array}$ & $\begin{array}{l}\text { Decreasing by } 10 \% \text { annually (currently } \\
\$ 1830 / \mathrm{kW} \text { ), plus } 30 \% \text { Federal tax credit }\end{array}$ \\
\hline Long Term Target & $\begin{array}{l}\$ 5000 / \text { unit }^{\mathrm{a}} \text { and } 5.3 \mathrm{M} \text { units in } 2030 ; \\
1.4 \mathrm{M} \text { units in } 2020 \text { (Japan } \\
\text { Government) [68] }\end{array}$ & $\$ 1300 / \mathrm{kW}$ in 2020 (U.S. DOE) \\
\hline
\end{tabular}

$\mathrm{NG}=$ natural gas; LNG = liquefied natural gas; DOE = Department of Energy

a Total price to consumer, including delivery and installation

Micro CHP has received much attention recently for household applications [69] and in novel

261 micro grid deployments [70], and past studies have highlighted system efficiency and system flexibility

262 [71]. Joint development of fuel cell micro CHP in Japan is organized by several organizations such as the

263 New Energy and Industrial Technology Development Organization (NEDO), the Fuel Cell

264 Commercialization Conference in Japan (FCCJ), and governmental organizations. Additionally, the

265 Advanced Co-generation and Energy Utilization Center Japan (ACEJ) works to advance Ene-farm sales

266 and maintenance activities through publications and training programs. Under this arrangement, joint

267 development is conducted by city gas companies, LPG companies, and industrial partners including

268 Toshiba Fuel Cell Power Systems, Aisin Seiki, and Panasonic [72]. In contrast, U.S. development is more

269 confined within single companies such as Bloom Energy and Fuel Cell Energy. For a given market, there

270 are more players and a more competitive environment in Japan whereas there are fewer players in

271 stationary power market segments in the U.S. For example, Bloom Energy is virtually the only supplier

272 for medium sized commercial markets from 100 to $350 \mathrm{~kW}$, with the Doosan/UTC Power phosphoric-

273 acid fuel cell (PAFC) system starting at $400 \mathrm{~kW}$. 
Both U.S. and Japan develop multiple fuel cell technologies. The Ene-farm program has both PEM (Toshiba, Panasonic) and SOFC (Aisin Seiki) market entrants with PEM capturing most of the market share at present. In the U.S., the mid-sized commercial market is represented by SOFC (Bloom 277 Energy), phosphoric acid fuel cells (Doosan/UTC Power), and molten-carbonate fuel cell systems at the 278 MW-sizes.

The Japan Ene-farm product features a much smaller fuel cell power level than the fuel cell

280 systems in the California SGIP - almost two orders of magnitude smaller at the nominal 0.7-1 kW power

281 level. The Japan Ene-farm project is based on PEM fuel cell technology for the largest players (Toshiba 282 and Panasonic) and SOFC technology for other vendors including Aisin Seiki. The California SGIP is 283 also open to different fuel cell technologies, but current technology entrants are dominated by SOFC 284 technology, followed by molten-carbonate (MCFC) and PAFC technology. ${ }^{4}$ Distributed generation systems are more economically favorable in regions with high prices for electricity purchased from the grid and relatively low natural gas prices. The cost difference between the 287 price of electricity and the cost of natural gas, or spark spread, ${ }^{5}$ is about twice as high in Japan for both sectors as it is in the U.S. as Japan has a much higher cost of electricity compared to the U.S. for both residential and commercial sectors. There is also a significant difference in the types of companies producing fuel cells in the two 291 regions. In Japan, large, diverse and presumably more stable companies such as Toshiba and Panasonic 292 only receive a tiny fraction of annual total revenue from annual sales from micro-CHP, whereas U.S. 293 companies such as Bloom Energy and Fuel Cell Energy are dedicated fuel cell companies. UTC Power in 294 the U.S. was a part of a large conglomerate United Technologies, but was sold to ClearEdge in 2013 295 (which subsequently filed for bankruptcy in 2014 and was purchased by Korean conglomerate Doosan).

\footnotetext{
${ }^{4}$ The following website has a map of California fuel-cell installations: http://www.nfcrc.uci.edu/3/FUEL_CELL_INFORMATION/CALIFORNIA_INSTALLATIONS/index.aspx, accessed on 22 December 2016.

${ }^{5}$ More exactly, the spark spread is defined by the following equation: Spark spread $(\$ / \mathrm{MWh})=$ power price $(\$ / \mathrm{MWh})-[$ natural gas price $(\$ / \mathrm{mmBtu}) *$ heat rate $(\mathrm{mmBtu} / \mathrm{MWh})]$, where the heat rate for a natural gas combined cycle gas plants is typically at $7000 \mathrm{Btu} / \mathrm{kWh}$, or a conversion efficiency of about $50 \%$.
} 


\section{Data Collection and Cost Reduction Disaggregation Approach}

Data from California's SGIP program is drawn from a publically available database of

298 information managed by the California Center for Sustainable Energy [73]. Cost data from this database

299 represents total eligible system costs and thus includes non-fuel cell "balance of plant" or "balance of

300 system" costs such as power electronics and air handling subsystems as well as installation costs. SGIP

301 installed costs included systems that have been approved and/or constructed and are split into technology

302 type (SOFC, PEM, PAFC, or MCFC). Data for fuel cell micro-CHP in Japan is drawn from market

303 sources and publicly reported cost data from fuel cell-related websites and from technical conferences and

304 trade shows.

305 In disaggregating experience curves and cost reduction, contributions from economies of scale,

306 product design improvements, learning by doing, and competition are expected. The approach for

307 disaggregating cost reductions is as follows and is depicted in Figure 1:

308

309

310

311

312

313

314

315

316

317

318

319
1. Determine learning rate from experience curve constructed with annual sales and price data.

2. Develop a manufacturing cost model or adopt an adjacent technology cost model, describing

a. Manufacturing cost versus annual production volume

b. Manufacturing cost dependence on critical materials

c. Product performance specifications and/or parametric relationships with cost

3. Obtain knowledge of number of manufacturers and manufacturing volumes over time. From this, estimate the increase in production volume as an input to manufacturing cost model.

4. Obtain information on product design. From this estimate changes in product materials, configuration, and/or layout as inputs to the manufacturing cost model.

Key steps are thus determining the increase in manufacturing volume from year 1 to year $\mathrm{N}$ and translating product design, performance, and integration information into cost reductions through material savings, assembly savings, or process impacts on cost model. 


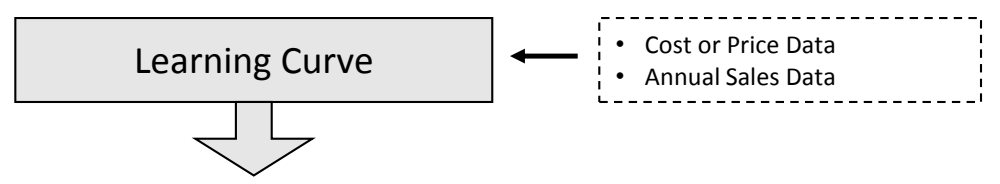

\section{Observed Price Reduction}
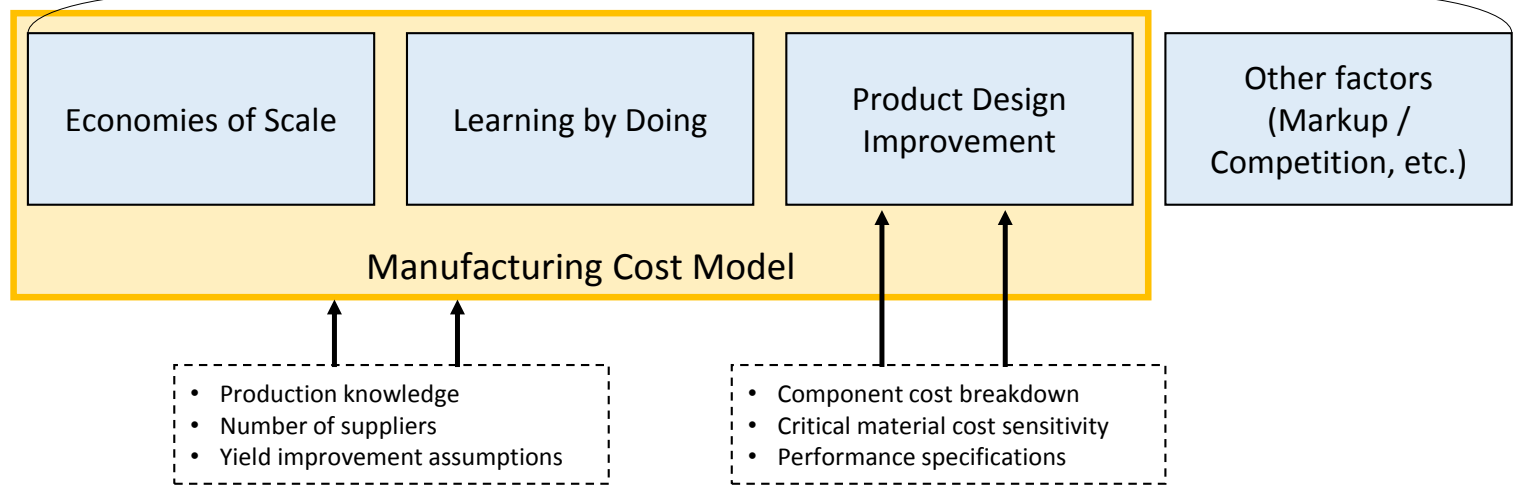

Figure 1 shows the observed cost reduction disaggregated into economies of scale, learning by "other factors" such as product mark-up and marketplace competition. In practice, "learning-by-doing" -interpreted here as manufacturing process learning or improvements in factory productivity or factory yield (i.e. the ratio of saleable output to material inputs) over time -- will not be directly observable. One way for accounting for this is as an adjustable parameter in the manufacturing cost model that has the general functional behavior of monotonically improving yield with increased volume of production whose functional dependence may be drawn from other manufacturing technologies. modeling approach; an alternative "top-down" approach might focus more on market structure, pricing strategy and pricing power on the supply side. The bottom-up approach is analytically tractable in the sense that it can utilize publically available data such as the cost or cost trends of components installation costs, while other cost factors can be obtained from publically available market reports. 
In addition to a suitable manufacturing cost model, this approach assumes the availability of the data sets in Figure 1 that are inside of the dashed boxes. These may include:

\subsection{Annual Production Volume}

We model the Japanese market as being served by two primary vendors in the 2009-2015 time frame, Panasonic and Toshiba, who both produce PEM FC systems. These two primary vendors produced about 1,300 units in 2009 , increasing to about 20,000 units in 2014 . These assumptions are consistent with sources obtained through the U.S. Department of Energy and market reports in the general media [ 74].

\subsection{Fuel Cell System Cost Modeling Example}

The U.S. DOE has supported fuel cell system cost modeling for many years for both stationary [75] and automotive systems [76]. We choose the cost model of Wei et al. [75] for $1 \mathrm{~kW}$ systems as a representative cost model for this analysis. This is a bottom-up cost model for CHP fuel cell systems assuming a vertically integrated fuel cell stack manufacturer and largely purchased balance of plant components. Each stack component is modeled starting from equipment costs, and factoring in material, operating costs, and labor costs. Figure 2 shows the output of the modeled direct manufacturing costs of a $1 \mathrm{~kW}$ CHP PEM fuel cell system for a fuel cell stack vendor as a function of annual production volume and broken down by stack costs, fuel processor costs, and non-fuel processor balance of plant costs (e.g.,

361 power inverter, supporting pumps, and auxiliary boiler). The fuel processor is the subsystem that provides 362 hydrogen fuel to the fuel cell stack assuming a natural gas input line. In this case the fuel processor 
364 decompose the natural gas into hydrogen fuel.

365

366

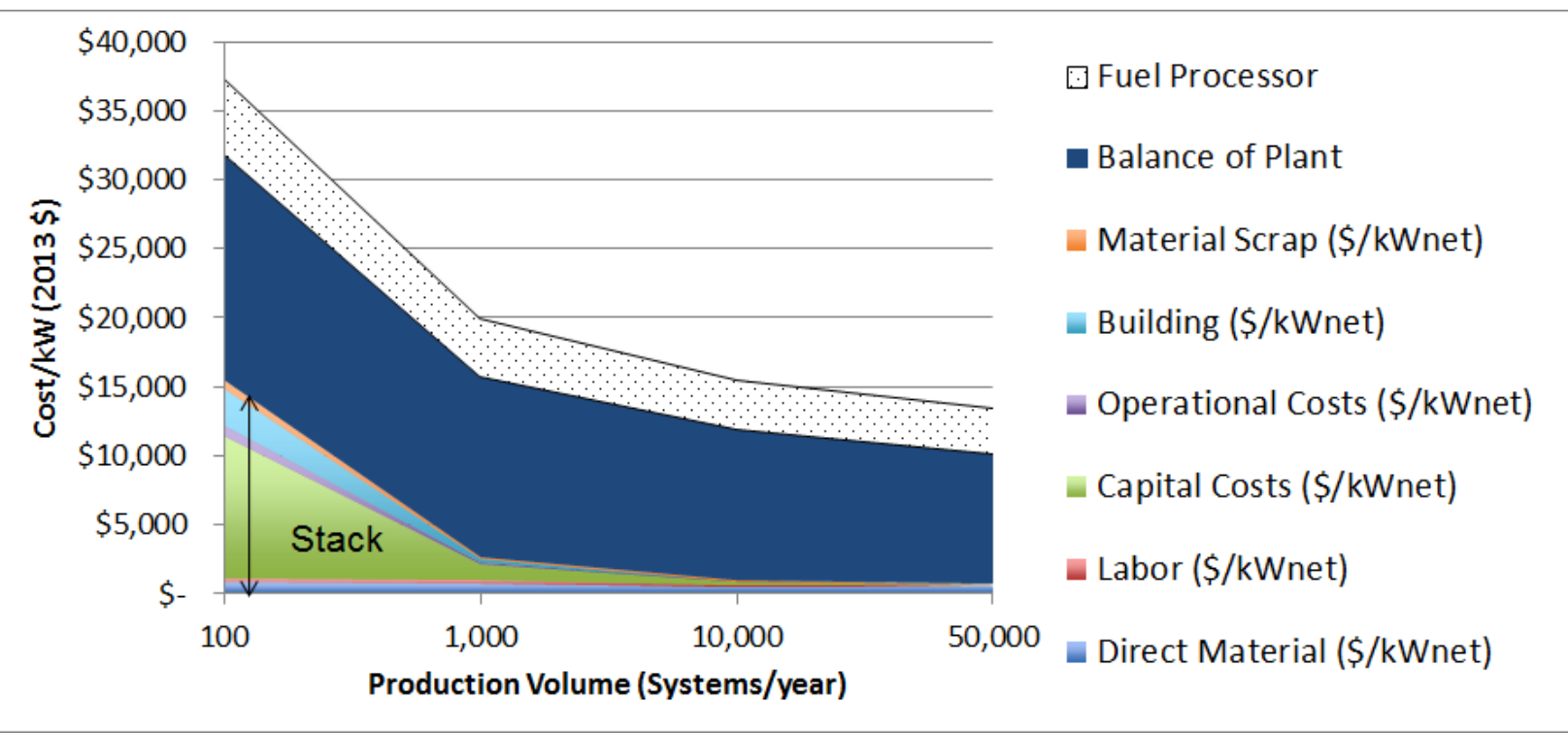

Figure 2. LBNL Direct Cost Model, $1 \mathrm{~kW}$ CHP system [75]. Overall system cost is dominated by balance of plant costs above an annual production volume of several hundred units per year. Note that this cost does not include corporate markups (e.g., sales and marketing and profit margin) and installation costs.

This depiction allows the delineation of fuel cell stack manufacturing costs ("Stack Cost" in Figure 2) and non-fuel cell components such as fuel processor and other balance of plant components. At higher production volumes, overall costs shifts from the fuel cell stack to the non-fuel cell stack components. As volume increases, the stack becomes a much smaller component of costs with the assumption that normalized fuel cell stack costs (cost per $\mathrm{kW})$ drop rapidly at higher volumes due to greater tool utilization and learning-by-doing manufacturing improvements such as defect inspection and real-time process control. One reason BOP costs are higher is because they are largely purchased off-theshelf components and a system vendor would pay equipment markups. Over time, BOP integration of components, in-house production, or supplier contract negotiations is expected to reduce these costs. Material costs are seen to be a very small portion of overall costs.

The largest cost reduction component with increasing annual production volume is the reduction in capital costs. This "economies of scale" is observed due to tool sets achieving a higher rate of 
utilization, and therefore capital (equipment) costs are amortized over a larger number of annual units. Material costs dominate at higher volume. The largest cost reduction is achieve from increasing annual production from 100 to 1,000 units, but thereafter about $20 \%$ cost reduction is achieved for every tentimes increase in annual production volume.

Actual market price in 2009 was about \$30,368 in 2013 U.S dollars (2013\$) corresponding to vendor production of about 1,300 units per year, and dropped to $\$ 15,239$ in 2014 at about 20,000 units per year and includes installation [77]. We choose 2014 as an end state year rather than 2015 for three reasons: (1) reports for performance improvements and system design improvements are from the 2012-

3922014 time frame; (2) the volume data in 2014 represents full calendar year sales, whereas 2015 may not; 393 and (3) the reported cost reduction from 2009-2014 and from 2009-2015 are very similar at 50\% and $39452 \%$, respectively. The cost model estimates a direct cost of $\$ 13,576$ per unit at 1,300 units per year for a 395 base $0.7 \mathrm{~kW}$ system. Increasing volume to 20,000 in 2014 reduces the modeled cost by $24 \%$ to $\$ 10,301$ 396 per system. Note that this modeled cost does not include corporate markups and installation costs. A corporate markup of $100 \%$ is assumed to cover general and administrative costs (G\&A), sales and marketing costs (S\&M) and other costs. Earlier financial analysis of publically-traded fuel cell companies in North America financial statements indicate a corporate markup of 40-50\% just for G\&A and S\&M. A 400 larger markup may be appropriate in the early commercialization phase to account for additional costs 401 such as non-recurring R\&D expenses and any product startup costs not accounted for in Figure 2. A 402 corporate markup of $100 \%$ would give a price of $\$ 27,151$ at 1,300 units per year and $\$ 20,601$ at 20,000 403 units per year. We take an installation factor of $10-20 \%$ additional cost, which yields an installed price 404 range of $\$ 29,866-\$ 32,581$ at 1,300 units per year to $\$ 22,661-\$ 24,721$ at 20,000 units per year versus the 405 observed $\$ 30,368$, and $\$ 15,239$ market prices. The cost model result implies to an approximate $24 \%$ cost 406 reduction due to economies of scale from 2009 through 2014. Note that Hiroshi [64] and METI [77] 407 report fuel cell prices in yen which are interpreted as nominal yen here. Accounting for inflation in Japan 408 gives a negligible correction to the learning rates computed for nominal yen. A fixed exchange rate of 
97.43 yen to the dollar was used to convert Japanese inflation-corrected yen values to 2013 US dollars in

the data below.

At the lower volume the LBNL modeled cost range is in close agreement with the observed market price, but at the higher volume, the cost model is $50-60 \%$ higher than the observed price since

413 product design, product performance, and corporate margins and installation price factor are held static.

414 In other words, the cost model result in Figure 2 gives an estimate of economies of scale from capital

415 cost, labor cost, material costs and other cost reductions that accrue from higher annual production

416 volume but not from other product design, performance, and integration improvements. Although the

417 LBNL cost model is in good agreement with the observed market price at the 1300 unit per year annual

418 volumes, there are multiple uncertainties that factor into the estimated range of total costs including

419 process yield, "make versus buy" decisions for system components, labor costs, and corporate markup, all

420 of which may change over time. The LBNL cost model assumes a high degree of automation above

4211,000 units per year and process yield for each stack module of approximately $80 \%{ }^{6}$ At this or lower

422 production volumes, costs may quite high if production facilities still rely on manual processing and

423 assembly which may drive up cycle times and labor costs and lower process yield. The LBNL cost model

424 was developed assuming a manufacturer in the US and some manufacturing costs are higher in Japan,

425 such as energy costs, although recent costs of labor are reasonably well matched ${ }^{7}$ and costs of

426 components may not differ significantly. The fuel cell stack process yield may be lower than that assumed

427 in the LBNL model due to the lack of fully developed and characterized process modules and immature

428 or insensitive defect metrology.

\footnotetext{
${ }^{6}$ An exception to this statement is that the fuel cell stack assembly module yield is assumed to be much higher than $80 \%$ since any loss at this step would necessitate scrapping all the value-added steps from other process modules. Overall Process yield is held fixed at the two annual production volumes of 1000 and 10,000 units per year. Actual "learning-by-doing" yield improvements from process learning, improved defect metrology, and real-time process control are expected but not known. However, since the fuel cell stack is in general a much smaller fraction of overall system costs than the balance of plant, this yield improvement factor is a not a major contribution to overall costs under these assumptions.

${ }^{7}$ Labor costs are well matched (see http://www.bls.gov/news.release/pdf/ichcc.pdf, accessed 20 March 2015.
} 

economies of scale for a more automated production facility. Another cost model for PEM CHP systems

431 funded by the DOE reports $20 \%$ cost reduction from 1,300 to 20,000 units [63], similar to the dependence

432 depicted here. The cost modeling approach offers a model of the economies of scale associated with

433 scaling up of production and improved capital utilization, i.e., it isolates the economy of scale factor. Note

434 that the economy of scale cost reduction factor in this case is independent of the corporate markup and 435 installation factors since we are assuming these two factors are constant scaling factors across the range of 436 annual manufacturing volumes.

\section{$437 \quad 3.3$ Cost reduction from reported product design improvements}

Information on product design is used to estimate changes in product materials, configuration,

and/or layout as an input to the cost model. Through published reports and conferences, material costs and design integration have been reported from both Toshiba and Panasonic.

For material costs both Toshiba and Panasonic report a 10-15\% reduction in number of cells and

$44220 \%$ reduction in platinum $(\mathrm{Pt})$ used $[68,74,78]$. A reduction in the number of cells corresponds to lower

443 Pt content by a proportional amount, so most of the Pt reduction is assumed be achieved from cell count

444 reduction rather than reduction in Pt areal-loading. From the LBNL cost model sensitivity analysis, this

445 translates into about $10 \%$ lower stack costs from lower material and assembly costs.

Toshiba reports $40 \%$ fewer components through improved design integration, for example the

447 transition from discrete inverter and control board to an integrated inverter and multilayer printed circuit

448 board [74]. We estimate this design integration translates to between 15-25\% lower balance of plant costs

449 from process consolidation and lower material costs.

450 The total cost reduction from cell count reduction and greater balance of plant integration can

451 then be inferred based on the relative mix of costs from the fuel cell stack and balance plant shown in

452 Figure 2. At 20,000 units per year, the fuel cell stack is estimated to make up about $10 \%$ of the total

453 system cost. Total unsubsidized price reduction from 2009-2014 thus is estimated to be $19 \%$ from product

454 performance and product design improvement. 


\section{Summary of Results}

Table 2 has a summary of experience curve learning rates. A learning rate of $18 \%$ is observed in Japan for fuel cell micro-CHP from 2005 to 2015 (Figure 3) versus a fairly flat learning rate for fuel cells systems in California (Figure 4). A learning rate in the range of 0-5\% is quoted in Table 2 for three different fuel cell technologies. The average learning rate for the three technologies in Figure 4 is $3.9 \%$, but all three of the three technologies (SOFC, PAFC, and MCFC) have a very poor fit and thus a flat

461 learning rate. The relatively flat learning rate in California is consistent with the very low learning rate for 462 early commercial SOFC systems in Europe reported in [57].

The Japan micro-CHP fuel cell system was in pre-commercialization phase from 2005-2008 and commercialized in 2009. According to Staffell and Green [60], prices dropped in 2008 in anticipation of commercial competition and then stayed flat in 2009 and 2010 as manufacturing costs caught up with sales prices. Because of this visible discontinuity in prices, we do not split the experience curve into a pre-commercialization and commercialization phase, since the large price drop in 2008 would lead to a higher learning rate from 2005-2008 (25\%) and the flat prices in 2009 and 2010 would lead to a lower learning rate from 2009-2014 (17\%), and both of these rates could be artifacts of the commercial pricing strategy in 2008. Since 2009, over 100,000 units have been delivered. The experience curve presented in

471 Figure 3 shows the cost reduction from 2009 to 2014 is estimated to be $50 \%$ using the data points on the 472 curve. The main data set is from Japan's Ministry of Economy, Trade and Industry (METI) [77]

Table 2. Summary of experience curve learning rates for stationary fuel cells considered in this work

\begin{tabular}{|c|c|c|}
\hline Product & Years & Learning Rate from this Work \\
\hline Stationary Fuel Cells & $2001-2015$ & LR (avg.) $\sim 0-5 \%$ (California) \\
& & LR $\sim 18 \%$ Japan Micro-CHP 2005-2015 \\
\hline
\end{tabular}




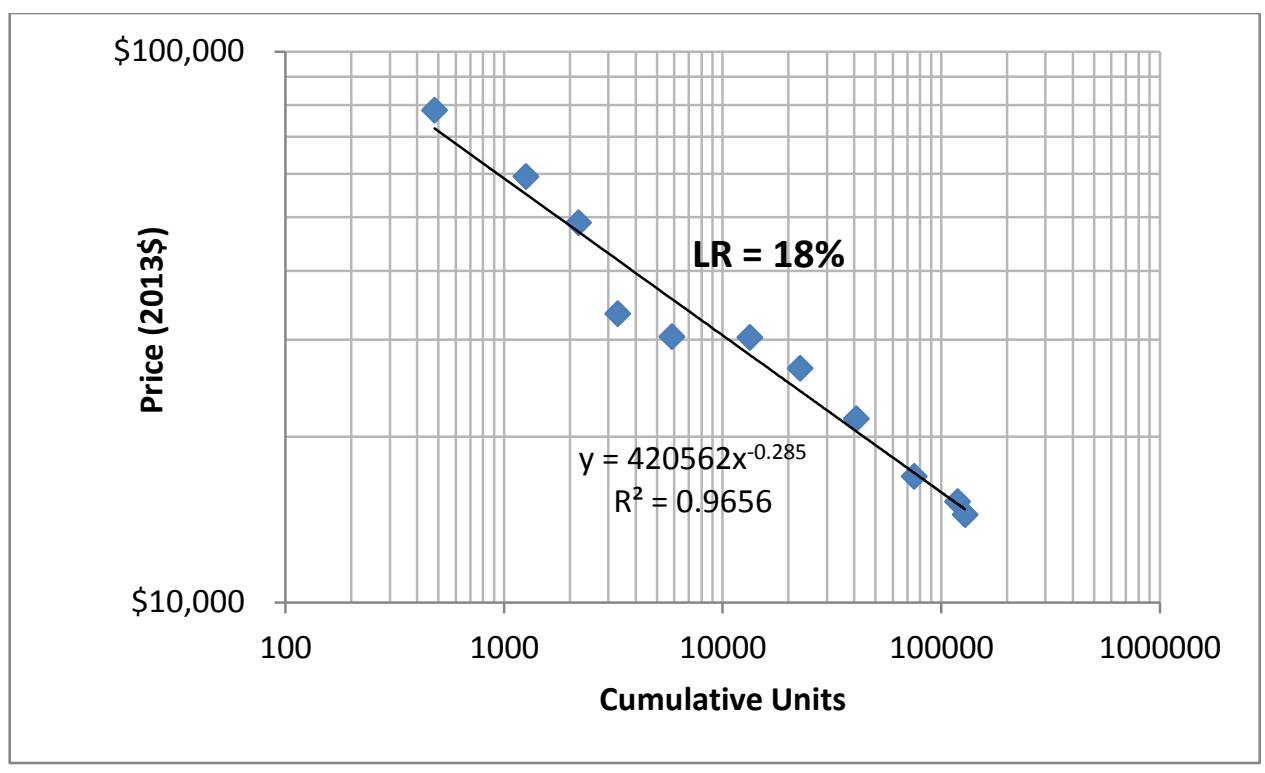

Figure 3. Observed cost reduction for Japan micro-CHP system cost from 2005-2015 with a learning rate of $18 \%$.

A table of cost reduction disaggregation elements is shown in Table 3. Overall cost reduction from 2009 to 2014 is $50 \%$, using reported system costs as shown by the data points in Figure 3 . If however, the price was reduced sharply in 2008 in preparation for the launch of the commercial phase in 2009, the cost reduction could be higher. Using the fit line in Figure 3, the cost reduction from 2009 to 2014 could be as high as 58\%. System vendor production volume increased by about one and a half orders of magnitude from approximately 1,300 units per year to about 20,000 units per year and is estimated to give $20-24 \%$ cost reduction from economies of scale from the cost modeling discussion above. Design improvements in fuel cell stack and balance of system components are estimated to contribute about $19 \%$ cost reduction as described above. This leaves a residual of $19-35 \%$ for cost reduction of other factors. In other words, the observed cost reduction can be explained by three components or roughly comparable magnitude: economies of scale, product design improvements, potential cost reductions in installation cost and other soft costs, and other factors. Other factors can include reduction in margin (smaller difference in market price to manufacturing cost) and purchased component cost savings from increased competition among suppliers. This latter factor is distinct from economies of scale since economies of scale implies a capital cost savings from increased tool utilization 
and material cost savings from volume discounts from a given vendor, but component price reductions

496 from increased buying power due to additional supplier competition is an additional factor. Note the

497 savings in Table 3 are not additive but rather represent the relative savings percentage for each element,

498 i.e., a total $50 \%$ savings is given by the expression $\left[1-(1-24 \%)^{*}(1-19 \%) *(1-19 \%)\right]$ or $[1-(1-20 \%) *(1-$

$49919 \%) *(1-23 \%)]$.

500

501 Table 3. Summary of cost reduction disaggregation in fuel cell micro-CHP in Japan from 2009-2014.

\begin{tabular}{|c|c|c|c|c|c|c|}
\hline Years & LR & $\begin{array}{c}\text { Cost } \\
\text { Reduction } \\
\text { (observed) }\end{array}$ & $\begin{array}{c}\text { Manufacturing } \\
\text { Cost Model }\end{array}$ & $\begin{array}{c}\text { Est. CR } \\
\text { from } \\
\text { Economies } \\
\text { of Scale }\end{array}$ & $\begin{array}{c}\text { Est. CR from } \\
\text { Technology/ } \\
\text { Design }\end{array}$ & $\begin{array}{c}\text { Est. CR from } \\
\text { Other factors } \\
\text { (Margin, } \\
\text { competition, } \\
\text { etc.) }\end{array}$ \\
\hline $\begin{array}{c}2005- \\
2014\end{array}$ & $18 \%$ & $50-58 \%$ & $\begin{array}{c}\text { Low Temperature } \\
\text { PEM CHP Direct } \\
\text { Manufacturing Cost } \\
\text { Model (Wei et al., } \\
\text { 2014) }\end{array}$ & $20-24 \%$ & $19 \%$ & $19-35 \%$ \\
\hline
\end{tabular}

$\mathrm{LR}=$ learning rate; $\mathrm{CR}=$ cost reduction

502

503

504

505

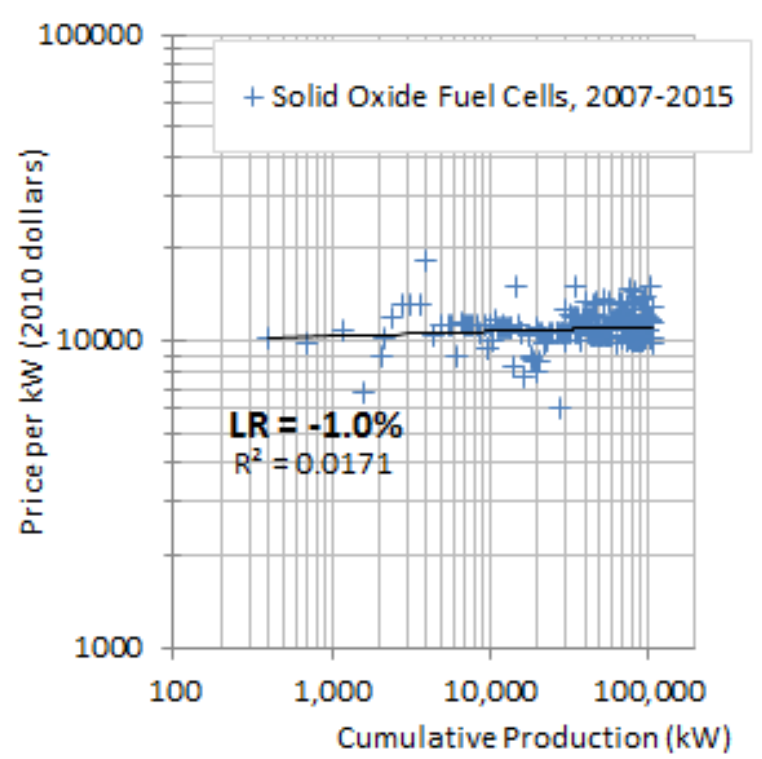

(a)

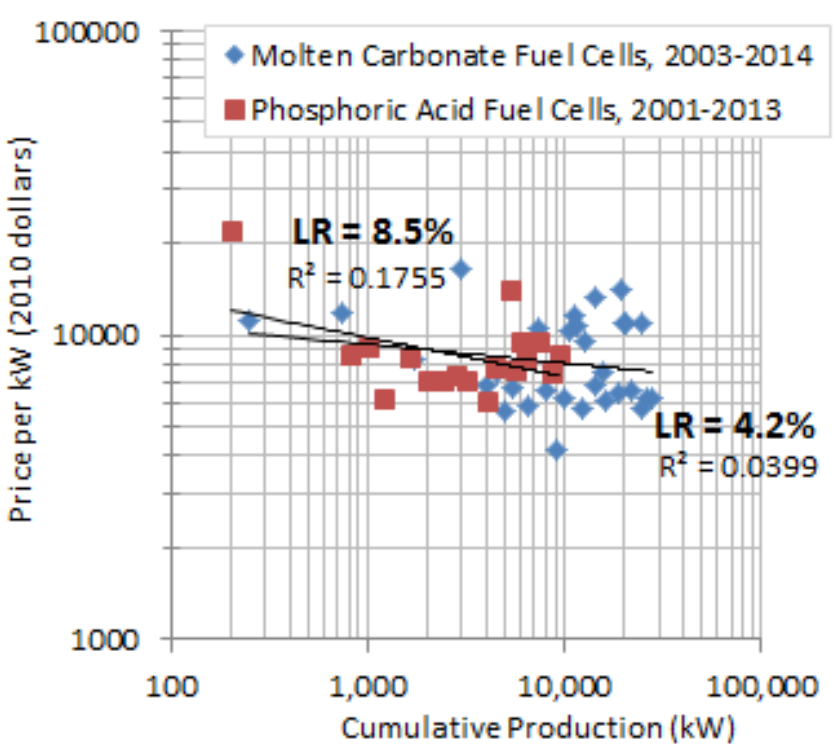

(b)

Figure 4. Reported costs of fuel cell total system cost per $\mathrm{kW}$ for the California SGIP program for (a) SOFC electric power systems, and (b) PAFC, and MCFC CHP systems. 
512 [73] is shown in Figure 4. Although the total installed power is comparable to the Japan CHP case (e.g.

$513100 \mathrm{MW}$ for SOFC), the number of installed units is much lower than the Japanese case because the size

514 per system is much higher (typically $400-700 \mathrm{~kW}$ ). There is a very low or near zero cost reduction

515 observed in California. (The face-value power-law learning rates for SOFC, PAFC, and MCFC in

516 California, are $-1 \%, 8.5 \%$, and $4.2 \%$, respectively, but in all cases the $\mathrm{R}^{2}$-fit is very low.) Note also that

517 over time, greater performance monitoring and reporting requirements for the SGIP program may have

518 contributed to higher system prices.

519 The California SGIP costs represent total system costs that are eligible for the state SGIP

520 incentive and thus includes installation costs in addition to capital costs. These system costs include

521 balance of plant costs such as fuel processor costs, air handling equipment, installation costs permitting

522 costs, and other soft costs. Since there are a range of possible installation sites and installation scenarios,

523 especially for the case of combined heat and power installations, there is an additional source of variation

524 in costs that has not been explored in this work. For example, some sites may have enclosures or pre-

525 poured concrete landing areas, some may have electrical connections in place already, some may be

526 linked to biogas systems, and so on. Normalizing across the range of heterogeneous installation and site-

527 specific factors would require detailed study of each site and was beyond the scope of this work. We

528 include systems from the SGIP database with the following status: (incentive) "payment completed," or

529 "payment in process," since these systems have been installed and have been verified in the field.

530 Including all non-suspended, non-cancelled projects in the database with in-process application status

531 (e.g., in "technical review" or "program administrator review") does not change the learning rate

532 conclusions.

The SOFC fuel cell system does not show any cost reduction. The SOFC vendor, Bloom Energy

534 has stated that the fuel cell module is $40 \mathrm{~kW}[79]$ and base system size is $200 \mathrm{~kW}$. The cumulative

535 volume of approximately $100 \mathrm{MW}$ thus represents about 500 systems units cumulative production or on

536 the order of hundreds of systems ( 20 MW) per year. For reference, the volumes shown in Figure 4a 
represent about eight doublings in volume. Assuming a constant learning rate of 5\%, 10\%, or $15 \%$, this number of doublings would correspond to an underlying cost reduction of $34 \%, 57 \%$, and $73 \%$, respectively, as opposed to the flat price trend that is observed. (corresponding to reported data from Doosan/UTC Power and Fuel Cell Energy, respectively), with

542 average system costs between $\$ 8,000-9,000$ per $\mathrm{kW}$. This data set represents a small number of units and

543 both of these technologies are more mature technologies compared to the SOFC case, so it is possible that

544 this data set represents a flat portion of the experience curve. For reference, the near term 2015 DOE

545 target for installed cost with natural gas is $\$ 3,000-4,000$ per $\mathrm{kW}$.

Both of these plots are segregated by geography, but limiting the micro-CHP data to Japan is

547 warranted because there is miniscule production of fuel cell micro-CHP systems outside of Japan.

548 California represents over $50 \%$ of the fuel cell market in the U.S., so the California SGIP database is a 549 reasonable representation of fuel cell system costs across the U.S. Table 4 shows a summary of subsidy or incentive levels for fuel cell micro-CHP in Japan and

551 SOFC fuel cell systems in California. In general, the annual percentage decrease in incentive levels are 552 much higher in Japan than California. The four-year average annual decrease from $2012-2015$ is $12 \%$ in 553 California compared to an average annual decrease of $26 \%$ in Japan. 


\begin{tabular}{|c|c|c|c|c|}
\hline & $\begin{array}{c}\text { California } \\
\text { SGIP } \\
\text { Incentive } \\
\text { for SOFC } \\
\text { Systems } \\
(2010 \$ / \mathrm{kW})\end{array}$ & $\begin{array}{c}\text { Annual } \\
\text { Percentage } \\
\text { Decrease }\end{array}$ & $\begin{array}{c}\text { under the SGIP program. } \\
\text { Japan } \\
\text { Subsidy } \\
\text { (1000 } \\
\text { Yen/Unit) } \\
{[68]}\end{array}$ & $\begin{array}{c}\text { Annual } \\
\text { Percentage } \\
\text { Decrease }\end{array}$ \\
\hline 2009 & & & 1400 & \\
\hline 2010 & 5000 & & 1300 & $7 \%$ \\
\hline 2011 & 3000 & $40 \%$ & 1030 & $21 \%$ \\
\hline 2012 & 2600 & $13 \%$ & 700 & $32 \%$ \\
\hline 2013 & 2270 & $13 \%$ & 450 & $36 \%$ \\
\hline 2014 & 2017 & $11 \%$ & 330 & $27 \%$ \\
\hline 2015 & 1816 & $10 \%$ & 300 & $9 \%$ \\
\hline 2015 & 1640 & $10 \%$ & & \\
\hline
\end{tabular}

\section{Discussion}

Some key considerations and differences in the Japan and California case are described in this

567 section including development, market, technology, and policy factors.

The target annual volume in 2020 and 2030 for Japan's micro CHP provides more "market

569 certainty" in the Japan case, where both fuel cell providers and supply chain vendors can count on a certain overall market volume trend and associated total revenue projection. From Table 4 above, the

571 declination is subsidies have been steeper in Japan than in California which may result in a greater

572 downward pressure on cost reduction in Japan than in the California market. Additionally, the market for

573 distributed power and CHP systems is more favorable in Japan due to the higher spark spread, which is

574 much larger in Japan as quantified above for residential and commercial markets.

577 would make it more appealing for companies to participate. A deeper understanding of the workings of

578 the joint development model and its benefits and tradeoffs may be needed in future analyses of similar

579 technologies. 
The Japan Ene-farm product features a much smaller fuel cell power level than the California

581 case and therefore the relative mix of non-fuel cell balance of plant and fuel-cell stack or fuel cell "hot

582 box" costs differ. Fuel cell stack costs are expected to be a higher component of overall system costs at

583 higher fuel cell power levels, as balance of plant costs are more "amortized" with larger system sizes [75].

584 If fuel cell stack cost reduction is very difficult, this may allow more nominal cost reduction for smaller

585 fuel cells systems through balance of plant costs reductions such as more integrated design of balance of

586 system components. Other possible differences in cost versus system size are safety measures such as leak

587 detection equipment, but this was not extensively studied in this report.

Japanese FC system suppliers are dominated by large, diverse companies such as Panasonic and

589 Toshiba in concert with large utility companies such as Tokyo Gas and Electric Company. An argument

590 could be made that this provides greater resources for more sustained development in Japan, compared to

591 dedicated fuel cell system companies more common in the U.S. The exception to this in the U.S. is UTC

592 Power, a subsidiary of a large, multinational corporation, United Technologies. However, the eventual

593 sale of UTC Power was potentially driven in part is because cost reduction is harder to achieve for larger

594 FC systems as noted above and perhaps UTC Power did not foresee a growing market with no national

595 mandate for sales volume in place as there is in Japan.

596 Exogenous factors should not be underestimated. The Fukushima nuclear accident in 2011 led to

597 a huge shift in primary energy consumption in Japan away from nuclear power, and fuel cell systems

598 figure prominently in Japan's most recent national energy plan. Before the Great East Japan Earthquake

599 and Tsunami March 2011, nuclear power constituted 28.6\% of primary energy in Japan [68]. After the

600 nuclear shutdowns stemming from the nuclear accidents at the Fukushima Nuclear Power Plant complex,

601 nuclear power plunged to only $1.7 \%$ of primary energy in Japan in 2012. During this time, the fraction of

602 primary energy from fossil fuels (oil, natural gas, and coal) increased from $62 \%$ prior to the tsunami to

$60388 \%$ in 2012. Thus there has been a greater impetus in Japan to develop greater energy efficiency and

604 install more distributed energy systems since this cataclysmic event. 

underlying cost of the fuel cell stack. Therefore, it is possible in the California case that the fuel cell stack

607 has achieved a level of cost reduction that is hidden within the overall system cost. More likely is that

608 U.S. fuel cell manufacturers are seeking to recoup their investment costs and may not have the resources

609 to invest heavily in R\&D. Also, there is less competition in the U.S. medium sized commercial power and 610 CHP markets: systems at 100-700 kW can be served by Bloom Energy SOFC (power only) systems; the 611 Doosan/UTC Power PAFC system is in multiples of $400 \mathrm{~kW}$; and Fuel Cell Energy's MCFC systems are 612 in the MW range, with virtually no other competitors. This marketplace of limited competition provides

613 less of a downward force on pricing and also limits the development of a diverse supply chain.

614 Understanding of the extent to which existing incentives may support prices in a less than competitive 615 environment could benefit from further investigation in the context of designing responsive deployment 616 and incentive programs.

Another important factor for the greater adoption of fuel cell systems is maintenance cost and in

618 particular equipment replacement costs as highlighted by Dodds et al.[61] for MCFC systems and

619 Ainscough, et al. for compressor reliability [80]. As capital costs or "first costs" are reduced, the life620 cycle cost and affordability of fuel cell systems could be limited in the future by equipment replacement 621 costs, e.g., the need for stack replacement costs after only a few years of operation or the need to replace 622 key component costs such as compressors or power inverters prior to the fuel cell system's full rated 623 lifetime. A detailed assessment of these costs is beyond the scope of this work but is an important area for 624 improvement and overall cost of ownership. The cost modeling approach is applicable to other technologies, but subject to the availability of a 626 suitable cost model showing cost dependency with production volume, data availability in production 627 volumes over time, and product design and performance information. A rough performance model, either 628 as part of the cost model or as an accompanying model element, is also needed in order to translate 629 reported performance and design improvements to material and manufacturing cost reductions. In the case 630 of the Japan micro-CHP market, all three elements of analysis are available: a readily available cost 
model, vendor production data, and publically reported system performance and design improvements. In

632 the case of SOFC technology in California, very little information has been available about system design 633 and performance changes over time. without detailed industry process knowledge and information such as critical defect densities, but follow up research can perhaps gain insights from historical data or modeling from other adjacent industries.

\section{6. Conclusions}

Learning rates are not static and evolve with technology learning, policy environments, and market changes. Here, we have described a promising further approach for integrating cost analysis

640 studies with observed learning rates that can be a framework to be applied to other technologies and

641 countries. Using this approach provide quantitative estimates for contributing mechanisms for cost

642 reductions in Japanese stationary fuel cell market that could not be revealed in earlier qualitative

643 approaches. The advantages of this approach are that it can provide bottom-up assessment of cost

644 reductions due to economies of scale, and either reported product performance and design improvements

645 or anticipated improvements can be directly modeled for potential future cost reductions. We would like

646 to see similar objective and quantitative approaches applied to other emerging and established

647 technologies to better understand the contributing factors and opportunities for technology cost reduction.

648 For example, this approach could be utilized to analyze the potential for future cost reductions in fuel cell

649 electric vehicles and battery electric vehicles. Similarly, experience curve datasets should be updated

650 regularly (e.g., annually or biannually) and this analysis approach is amenable to re-computation and

651 revision on a regular basis as well.

652 The Japan micro-CHP program benefits from several factors such as more favorable market 653 conditions (e.g. higher spark spread) and greater competition, while the recent exogenous shock of the 6542011 tsunami has also accelerated the policy and market acceptance of distributed generation and fuel cell 655 systems. The U.S. market is harder to enter due to much less expensive grid electricity and lower gas 656 prices, which make it harder for fuel cell distributed electricity systems to compete with grid electricity. 

as well as a long-term national mandate for the market adoption of FC CHP systems. The U.S. has not

659 supported joint development as widely. The Japan micro-CHP has had much greater cost reductions than

660 the California stationary fuel cell system market under the SGIP program with the micro-CHP case

661 having much higher unit volumes (number of systems per year) than FC systems in California.

662 To the extent that price data can be used as a rough proxy to infer technology learning and cost,

663 deployment programs in and of themselves may not lead to significant cost reduction, as seen in the

664 California fuel cell market. These programs may further require a strong development environment,

665 government mandates for market adoption, and in the case of fuel cell distributed generation, more

666 favorable market conditions and the presence of exogenous factors.

We demonstrate a bottom-up cost modeling approach that can been applied to disaggregate observed experience curve cost reduction and use the approach to estimate the cost reduction components in the Japanese micro-CHP program into three components: economies of scale, product design improvements, and other residual effects. This approach provides insight into the technology dependencies and economies of scale of product and system manufacturing and can be applied to other technologies. The approach requires a cost model framework and information about industry participants, vendor production volumes, and evolving product performance and design information.

678 Acknowledgements

679 This work was funded by the U.S. Department of Energy (DOE) Office of Energy Efficiency and

680 Renewable Energy, and conducted at Lawrence Berkeley National Laboratory under Contract No. DE681 AC02-05CH11231. 


\section{References}

1. Darrow, Ken, Rick Tidball, James Wang, and Anne Hampson. Catalog of CHP Technologies. (U.S. Environmental Protection Agency Combined Heat and Power Partnership, March 2015). https://doe.icfwebservices.com/chpdb/

2. U.S. Department of Energy (DOE) Fuel Cell Technologies Office Multi-Year Research, Development, and Demonstration Plan, Technical Plan - Fuel Cells, Section 3.4.4, Available at http://energy.gov/sites/prod/files/2014/12/f19/fcto myrdd fuel cells.pdf accessed 1 June, 2015.

3. Yun Wang, Ken S. Chen, Jeffrey Mishler, Sung Chan Cho, Xavier Cordobes Adroher, A review of polymer electrolyte membrane fuel cells: Technology, applications, and needs on fundamental research, Applied Energy, Volume 88, Issue 4, April 2011, Pages 981-1007, ISSN 0306-2619, http://dx.doi.org/10.1016/j.apenergy.2010.09.030.

4. Kui Jiao, Jaewan Park, Xianguo Li, Experimental investigations on liquid water removal from the gas diffusion layer by reactant flow in a PEM fuel cell, Applied Energy, Volume 87, Issue 9, September 2010, Pages 2770-2777, ISSN 0306-2619, http://dx.doi.org/10.1016/j.apenergy.2009.04.041.

5. Yong Tang, Wei Yuan, Minqiang Pan, Zongtao Li, Guoqing Chen, Yong Li, Experimental investigation of dynamic performance and transient responses of a $\mathrm{kW}$-class PEM fuel cell stack under various load changes, Applied Energy, Volume 87, Issue 4, April 2010, Pages 1410-1417, ISSN 0306-2619, http://dx.doi.org/10.1016/j.apenergy.2009.08.047.

6. Neelima Mahato, Amitava Banerjee, Alka Gupta, Shobit Omar, Kantesh Balani, Progress in material selection for solid oxide fuel cell technology: A review, Progress in Materials Science, Volume 72, July 2015, Pages 141-337, ISSN 0079-6425, http://dx.doi.org/10.1016/j.pmatsci.2015.01.001.

7. L. Barelli, G. Bidini, F. Gallorini, A. Ottaviano, Dynamic analysis of PEMFC-based CHP systems for domestic application, Applied Energy, Volume 91, Issue 1, March 2012, Pages 1328, ISSN 0306-2619, http://dx.doi.org/10.1016/j.apenergy.2011.09.008.

8. Xiaosong Hu, Lars Johannesson, Nikolce Murgovski, Bo Egardt, Longevity-conscious dimensioning and power management of the hybrid energy storage system in a fuel cell hybrid electric bus, Applied Energy, Volume 137, 1 January 2015, Pages 913-924, ISSN 0306-2619, http://dx.doi.org/10.1016/j.apenergy.2014.05.013.

9. Yong-Peng Wang, Xian-Wei Liu, Wen-Wei Li, Feng Li, Yun-Kun Wang, Guo-Ping Sheng, Raymond J. Zeng, Han-Qing Yu, A microbial fuel cell-membrane bioreactor integrated system for cost-effective wastewater treatment, Applied Energy, Volume 98, October 2012, Pages 230235, ISSN 0306-2619, http://dx.doi.org/10.1016/j.apenergy.2012.03.029.

10. E4tech, The Fuel Cell Industry Review 2014, November 2014. Available at http://www.e4tech.com/fuelcellindustryreview/, accessed on 10 December 2015.

11. Wright, T.P. (1936), "Factors Affecting the Cost of Airplanes", Journal of the Aeronautical Sciences, Vol. 3, No. 4, pp. 122-128. 
12. Weiss, M., M.K. Patel, H.M. Junginger, K. Blok (2009), A review of experience curve analyses for energy demand technologies, Technological Forecasting and Social Change, volume 77, issue 3 , pp. $411-428$.

13. R. Kannan, Uncertainties in key low carbon power generation technologies - Implication for UK decarbonisation targets, Applied Energy, Volume 86, Issue 10, October 2009, Pages 1873-1886, ISSN 0306-2619, http://dx.doi.org/10.1016/j.apenergy.2009.02.014.

14. Jamin Koo, Kyungtae Park, Dongil Shin, En Sup Yoon, Economic evaluation of renewable energy systems under varying scenarios and its implications to Korea's renewable energy plan, Applied Energy, Volume 88, Issue 6, June 2011, Pages 2254-2260, ISSN 0306-2619, http://dx.doi.org/10.1016/j.apenergy.2010.12.063.

15. Hall, Graham and Sydney Howell. 1985. The experience curve from the economist's perspective, Strategic Management Journal 6, No. 3, 1097-0266.

16. Nykvist, B., and M. Nilsson. 2015. "Rapidly falling costs of battery packs for electric vehicles." Nature Climate Change 5: 329-332.

17. Sonia Yeh, Edward S. Rubin, A review of uncertainties in technology experience curves, Energy Economics, Volume 34, Issue 3, May 2012, Pages 762-771, ISSN 0140-9883, http://dx.doi.org/10.1016/j.eneco.2011.11.006.

18. Åsa Lindman, Patrik Söderholm, Wind power learning rates: A conceptual review and metaanalysis, Energy Economics, Volume 34, Issue 3, May 2012, Pages 754-761, ISSN 0140-9883, http://dx.doi.org/10.1016/j.eneco.2011.05.007.

19. Louis-Benoit Desroches, Karina Garbesi, Colleen Kantner, Robert Van Buskirk, Hung-Chia Yang, Incorporating experience curves in appliance standards analysis, Energy Policy, Volume 52, January 2013, Pages 402-416, ISSN 0301-4215, http://dx.doi.org/10.1016/j.enpol.2012.09.066.

20. Martin Weiss, Martin K. Patel, Martin Junginger, Adolfo Perujo, Pierre Bonnel, Geert van Grootveld, On the electrification of road transport - Learning rates and price forecasts for hybridelectric and battery-electric vehicles, Energy Policy, Volume 48, September 2012, Pages 374393, ISSN 0301-4215, http://dx.doi.org/10.1016/j.enpol.2012.05.038.

21. Bob van der Zwaan, Rodrigo Rivera-Tinoco, Sander Lensink, Paul van den Oosterkamp, Cost reductions for offshore wind power: Exploring the balance between scaling, learning and R\&D, Renewable Energy, Volume 41, May 2012, Pages 389-393, ISSN 0960-1481, http://dx.doi.org/10.1016/j.renene.2011.11.014.

22. P Thompson, The Relationship between Unit Cost and Cumulative Quantity and the Evidence for Organizational Learning-by-Doing, The Journal of Economic Perspectives, Volume 26, Number 3, Summer 2012, pp. 203-224(22)

23. Edward S. Rubin, Inês M.L. Azevedo, Paulina Jaramillo, Sonia Yeh, A review of learning rates for electricity supply technologies, Energy Policy, Volume 86, November 2015, Pages 198-218, ISSN 0301-4215, http://dx.doi.org/10.1016/j.enpol.2015.06.011. 
24. Nagy B, Farmer JD, Bui QM, Trancik JE (2013) Statistical Basis for Predicting Technological Progress. PLoS ONE 8(2): e52669. doi: 10.1371/journal.pone.0052669

25. Haysom, J. E., Jafarieh, O., Anis, H., Hinzer, K., and Wright, D. (2015) Learning curve analysis of concentrated photovoltaic systems. Prog. Photovolt: Res. Appl., 23: 1678-1686. doi: 10.1002/pip.2567.

26. Mark Winskel, Nils Markusson, Henry Jeffrey, Chiara Candelise, Geoff Dutton, Paul Howarth, Sophie Jablonski, Christos Kalyvas, David Ward, Learning pathways for energy supply technologies: Bridging between innovation studies and learning rates, Technological Forecasting and Social Change, Volume 81, January 2014, Pages 96-114, ISSN 0040-1625, http://dx.doi.org/10.1016/j.techfore.2012.10.015.

27. Richard Lohwasser, Reinhard Madlener, Relating R\&amp;D and investment policies to CCS market diffusion through two-factor learning, Energy Policy, Volume 52, January 2013, Pages 439-452, ISSN 0301-4215, http://dx.doi.org/10.1016/j.enpol.2012.09.061.

28. T. Wiesenthal, P. Dowling, J. Morbee, C. Thiel, B. Schade, P. Russ, S. Simoes, S. Peteves, K. Schoots, M. Londo, et al., Technology Learning Curves for Energy Policy Support, JRC Policy and Scientific Reports, European Commission Joint Research Centre, Institute for Prospective Technological Studies, Institute for Energy and Transport, 2012.

29. Govinda R. Timilsina, Lado Kurdgelashvili, Patrick A. Narbel, Solar energy: Markets, economics and policies, Renewable and Sustainable Energy Reviews, Volume 16, Issue 1, January 2012, Pages 449-465, ISSN 1364-0321, http://dx.doi.org/10.1016/j.rser.2011.08.009.

30. Van Buskirk, R.D., C. L. S. Katner, B. F. Gerke, and S. Chu (2014), “A retrospective investigation of energy efficiency standards: policies may have accelerated long term declines in appliance costs". Environmental Research Letters, Vol. 9, pp. 114010-114021.

31. Wei, M., S. Smith, M. Sohn, (2015), "Non-Constant Learning Rates in Retrospective Experience Curve Analyses and their Correlation to Deployment Programs," Lawrence Berkeley National Lab Report, April 2015

32. Breyer, C. and Gerlach, A. (2013), Global overview on grid-parity. Prog. Photovolt: Res. Appl., 21: 121-136. doi:10.1002/pip.1254

33. Arnaud de La Tour, Matthieu Glachant, Yann Ménière, Predicting the costs of photovoltaic solar modules in 2020 using experience curve models, Energy, Volume 62, 1 December 2013, Pages 341-348, ISSN 0360-5442, http://dx.doi.org/10.1016/j.energy.2013.09.037.

34. Sheng Li, Xiaosong Zhang, Lin Gao, Hongguang Jin, Learning rates and future cost curves for fossil fuel energy systems with CO2 capture: Methodology and case studies, Applied Energy, Volume 93, May 2012, Pages 348-356, ISSN 0306-2619, http://dx.doi.org/10.1016/j.apenergy.2011.12.046.

35. J. Hernández-Moro, J.M. Martínez-Duart, Analytical model for solar PV and CSP electricity costs: Present LCOE values and their future evolution, Renewable and Sustainable Energy Reviews, Volume 20, April 2013, Pages 119-132, ISSN 1364-0321, http://dx.doi.org/10.1016/j.rser.2012.11.082. 
834

835

836

837

838

839

840

841

842

843

844

845

846

847

848

849

850

851

852

853

854

855

856

857

858

859

860

861

862

863

864

865

866

867

868

869

870

871

872

873

874

875

876

877

878

879

880

881

882

883

884

36. Jennifer A. Hayward, Paul W. Graham, A global and local endogenous experience curve model for projecting future uptake and cost of electricity generation technologies, Energy Economics, Volume 40, November 2013, Pages 537-548, ISSN 0140-9883, http://dx.doi.org/10.1016/j.eneco.2013.08.010.

37. D.L. Talavera, P. Pérez-Higueras, J.A. Ruíz-Arias, E.F. Fernández, Levelised cost of electricity in high concentrated photovoltaic grid connected systems: Spatial analysis of Spain, Applied Energy, Volume 151, 1 August 2015, Pages 49-59, ISSN 0306-2619, http://dx.doi.org/10.1016/j.apenergy.2015.04.072.

38. Patrick André Narbel, Jan Petter Hansen, Estimating the cost of future global energy supply, Renewable and Sustainable Energy Reviews, Volume 34, June 2014, Pages 91-97, ISSN 13640321, http://dx.doi.org/10.1016/j.rser.2014.03.011.

39. Stefan Reichelstein, Michael Yorston, The prospects for cost competitive solar PV power, Energy Policy, Volume 55, April 2013, Pages 117-127, ISSN 0301-4215, http://dx.doi.org/10.1016/j.enpol.2012.11.003.

40. Amy J.C. Trappey, Charles V. Trappey, Penny H.Y. Liu, Lee-Cheng Lin, Jerry J.R. Ou, A hierarchical cost learning model for developing wind energy infrastructures, International Journal of Production Economics, Volume 146, Issue 2, December 2013, Pages 386-391, ISSN 09255273, http://dx.doi.org/10.1016/j.ijpe.2013.03.017.

41. Joern Huenteler, Christian Niebuhr, Tobias S. Schmidt, The effect of local and global learning on the cost of renewable energy in developing countries, Journal of Cleaner Production, Volume 128, 1 August 2016, Pages 6-21, ISSN 0959-6526, http://dx.doi.org/10.1016/j.jclepro.2014.06.056.

42. P. Criqui, S. Mima, P. Menanteau, A. Kitous, Mitigation strategies and energy technology learning: An assessment with the POLES model, Technological Forecasting and Social Change, Volume 90, Part A, January 2015, Pages 119-136, ISSN 0040-1625, http://dx.doi.org/10.1016/j.techfore.2014.05.005.

43. Rong-Gang Cong, An optimization model for renewable energy generation and its application in China: A perspective of maximum utilization, Renewable and Sustainable Energy Reviews, Volume 17, January 2013, Pages 94-103, ISSN 1364-0321, http://dx.doi.org/10.1016/j.rser.2012.09.005.

44. Matthias Kalkuhl, Ottmar Edenhofer, Kai Lessmann, Learning or lock-in: Optimal technology policies to support mitigation, Resource and Energy Economics, Volume 34, Issue 1, January 2012, Pages 1-23, ISSN 0928-7655, http://dx.doi.org/10.1016/j.reseneeco.2011.08.001.

45. Hans-Paul Siderius, The role of experience curves for setting MEPS for appliances, Energy Policy, Volume 59, August 2013, Pages 762-772, ISSN 0301-4215, http://dx.doi.org/10.1016/j.enpol.2013.04.032.

46. Andrew MacGillivray, Henry Jeffrey, Mark Winskel, Ian Bryden, Innovation and cost reduction for marine renewable energy: A learning investment sensitivity analysis, Technological Forecasting and Social Change, Volume 87, September 2014, Pages 108-124, ISSN 0040-1625, http://dx.doi.org/10.1016/j.techfore.2013.11.005. 
922

923

924

925

926

927

928

929

930

931

932

933

934

47. Cheng Zheng, Daniel M. Kammen, An innovation-focused roadmap for a sustainable global photovoltaic industry, Energy Policy, Volume 67, April 2014, Pages 159-169, ISSN 0301-4215, http://dx.doi.org/10.1016/j.enpol.2013.12.006.

48. Robert Wand, Florian Leuthold, Feed-in tariffs for photovoltaics: Learning by doing in Germany?, Applied Energy, Volume 88, Issue 12, December 2011, Pages 4387-4399, ISSN 0306-2619, http://dx.doi.org/10.1016/j.apenergy.2011.05.015.

49. Yueming Qiu, Laura D. Anadon, The price of wind power in China during its expansion: Technology adoption, learning-by-doing, economies of scale, and manufacturing localization, Energy Economics, Volume 34, Issue 3, May 2012, Pages 772-785, ISSN 0140-9883, http://dx.doi.org/10.1016/j.eneco.2011.06.008.

50. Morgan Bazilian, Ijeoma Onyeji, Michael Liebreich, Ian MacGill, Jennifer Chase, Jigar Shah, Dolf Gielen, Doug Arent, Doug Landfear, Shi Zhengrong, Re-considering the economics of photovoltaic power, Renewable Energy, Volume 53, May 2013, Pages 329-338, ISSN 09601481, http://dx.doi.org/10.1016/j.renene.2012.11.029.

51. Alan Goodrich, Ted James, and Michael Woodhouse, Residential, Commercial, and Utility-Scale Photovoltaic (PV) System Prices in the United States: Current Drivers and Cost-Reduction Opportunities, National Renewable Laboratory Technical Report NREL/TP-6A20-53347 February 2012.

52. Chiara Candelise, Mark Winskel, Robert J.K. Gross, The dynamics of solar PV costs and prices as a challenge for technology forecasting, Renewable and Sustainable Energy Reviews, Volume 26, October 2013, Pages 96-107, ISSN 1364-0321, http://dx.doi.org/10.1016/j.rser.2013.05.012.

53. Peck Yean Gan, ZhiDong Li, Quantitative study on long term global solar photovoltaic market, Renewable and Sustainable Energy Reviews, Volume 46, June 2015, Pages 88-99, ISSN 13640321, http://dx.doi.org/10.1016/j.rser.2015.02.041.

54. Marc de Wit, Martin Junginger, André Faaij, Learning in dedicated wood production systems: Past trends, future outlook and implications for bioenergy, Renewable and Sustainable Energy Reviews, Volume 19, March 2013, Pages 417-432, ISSN 1364-0321, http://dx.doi.org/10.1016/j.rser.2012.10.038.

55. Roberto F. Aguilera, Production costs of global conventional and unconventional petroleum, Energy Policy, Volume 64, January 2014, Pages 134-140, ISSN 0301-4215, http://dx.doi.org/10.1016/j.enpol.2013.07.118.

56. Sheng Li, Hongguang Jin, Lin Gao, Xiaosong Zhang, Xiaozhou Ji, Techno-economic performance and cost reduction potential for the substitute/synthetic natural gas and power cogeneration plant with CO2 capture, Energy Conversion and Management, Volume 85, September 2014, Pages 875-887, ISSN 0196-8904, http://dx.doi.org/10.1016/j.enconman.2013.12.071.

57. Rivera-Tinoco, Rodrigo, Koen Schoots, Bob van der Zwaan (2012), Learning curves for solid oxide fuel cells Energy Conversion and Management, Vol. 57, pp. 86-96, doi:10.1016/j.enconman.2011.11.018. 
58. Schoots, K., G.J. Krame, B.C.C. van der Zwaan (2010), Technology learning for fuel cells: An assessment of past and potential cost reductions, Energy Policy 38, 2887-2897.

59. Thomas Mayer, Danny Kreyenberg, Jörg Wind, Frank Braun, Feasibility study of 2020 target costs for PEM fuel cells and lithium-ion batteries: A two-factor experience curve approach, International Journal of Hydrogen Energy, Volume 37, Issue 19, October 2012, Pages 1446314474, ISSN 0360-3199, http://dx.doi.org/10.1016/j.ijhydene.2012.07.022.

60. Staffell, I., R. Green (2013), The cost of domestic fuel cell micro-CHP systems, International Journal of Hydrogen Energy 38 (2), 1088-1102.

61. Paul E. Dodds, Iain Staffell, Adam D. Hawkes, Francis Li, Philipp Grünewald, Will McDowall, Paul Ekins, Hydrogen and fuel cell technologies for heating: A review, International Journal of Hydrogen Energy, Volume 40, Issue 5, 9 February 2015, Pages 2065-2083, ISSN 0360-3199, http://dx.doi.org/10.1016/j.ijhydene.2014.11.059.

62. Harikishan R. Ellamla, Iain Staffell, Piotr Bujlo, Bruno G. Pollet, Sivakumar Pasupathi, Current status of fuel cell based combined heat and power systems for residential sector, Journal of Power Sources, Volume 293, 20 October 2015, Pages 312-328, ISSN 0378-7753, http://dx.doi.org/10.1016/j.jpowsour.2015.05.050.

63. James, B.D., A.B. Spisak, W.G. Colella, "Manufacturing Cost Analysis of Stationary Fuel Cell Systems." Strategic Analysis, September 7, 2012.

64. Hiroshi Ito, Economic and environmental assessment of residential micro combined heat and power system application in Japan, International Journal of Hydrogen Energy, Volume 41, Issue 34, 14 September 2016, Pages 15111-15123, ISSN 0360-3199, http://dx.doi.org/10.1016/j.ijhydene.2016.06.099.

65. Neij, Lena (2008), Cost development of future technologies for power generation-A study based on experience curves and complementary bottom-up assessments, Energy Policy, 36, 2200-2211, ISSN 0301-4215, http://dx.doi.org/10.1016/j.enpol.2008.02.029.

66. Lipman, T., D. Sperling (1999), Forecasting the cost of automotive PME fuel cell systemsusing bounded manufacturing progress functions, Proceedings for the IEA International workshop "Experience curves for policy making-the case of energy technologies". May 10-11, 1999, Stuttgart, Germany.

67. H. Tsuchiya, O. Kobayashi (2004), Mass production cost of PEM fuel cell by learning curve, Hydrogen Energy, 29, pp. 985-990.

68. Shimuzu, Toshiki, "Evolution of "Ene-Farm" and the Activities for the Market Expansion," Panasonic Corporation, Fuel Cell Expo Technical Conference Session FC-1, Tokyo Japan, Feb $25,2015$.

69. Enrico Saverio Barbieri, Pier Ruggero Spina, Mauro Venturini, Analysis of innovative microCHP systems to meet household energy demands, Applied Energy, Volume 97, September 2012, Pages 723-733, ISSN 0306-2619, http://dx.doi.org/10.1016/j.apenergy.2011.11.081.

70. Georgios M. Kopanos, Michael C. Georgiadis, Efstratios N. Pistikopoulos, Energy production planning of a network of micro combined heat and power generators, Applied Energy, Volume 
986
102, February 2013, Pages 1522-1534, ISSN 0306-2619, http://dx.doi.org/10.1016/j.apenergy.2012.09.015.

71. Thomas Nuytten, Bert Claessens, Kristof Paredis, Johan Van Bael, Daan Six, Flexibility of a combined heat and power system with thermal energy storage for district heating, Applied Energy, Volume 104, April 2013, Pages 583-591, ISSN 0306-2619, http://dx.doi.org/10.1016/j.apenergy.2012.11.029.

72. Kasuh, Takahiro (2015), Why does Japan believe in domestic fuel cell? Adaptation to European market?, Osaka Gas Co. Ltd., EGATEC2013, European Gas Technology Conference, Paris, 3031 May 2013. Available at: http://www.marcogaz.org/downloads/EGATEC2013/Day2May31/PS5/PS5f_6_Kasuh.pdf, accessed on 15 October 2015.

73. California Self-Generation Incentive Program, "Weekly Statewide Report". Available at https://energycenter.org/self-generation-incentive-program/program-statistics, accessed 22 December 2016.

74. Kume, Hideyoshi (2014), “Toshiba Revamps 'Ene Farm' Residential Fuel Cell,” FuelCellWorks News, Available at http://fuelcellsworks.com/news/2012/01/24/toshiba-revamps-ene-farmresidential-fuel-cell/, accessed 2 December 2014.

75. Wei, M., T. Lipman, et al. (2014), “A Total Cost of Ownership Model for Low Temperature PEM Fuel Cells in Combined Heat and Power and Backup Power Applications," Lawrence Berkeley National Laboratory Report, November 2014. Available at http://ses.lbl.gov/publications/totalcost-ownership-model-low, accessed 1 December 2014.

76. Marcinkoski, Jason, Brian D. James, Jeff A. Kalinoski, Walt Podolski, Thomas Benjamin, John Kopasz, Manufacturing process assumptions used in fuel cell system cost analyses, Journal of Power Sources, Volume 196, Issue 12, 15 June 2011, Pages 5282-5292, ISSN 0378-7753, http://dx.doi.org/10.1016/j.jpowsour.2011.02.035.

77. Ministry of Economy, Trade and Industry (METI). Document for the Committee of Hydrogen and Fuel Cells [in Japanese] (2015) available at: http://www.meti.go.jp/committee/kenkyukai/energy/suiso_nenryodenchi/pdf/004_01_00.pdf

78. Panasonic Residential Fuel Cell, Specifications of a Residential fuel cell unit for a detached house, available at http://panasonic.co.jp/ap/FC/en_about_01.html, accessed 21 December 2016.

79. Bloom Energy, A New Energy Solution - New England Roundtable. Available at http://www.raabassociates.org/Articles/Fox\%20Presentation\%20for\%20Posting\%20after10.26.12 \%20Roundtable.pdf, accessed 10 March 2015.

80. Chris Ainscough, Jennifer Kurtz, Keith Wipke, Sam Sprik, Leslie Eudy, Genevieve Saur, Todd Ramsden, Performance \& Reliability of Fuel Cell Systems in the Field Fuel Cell End Users' Forum, 4 February 2013. Available at http://www.nrel.gov/hydrogen/cfm/pdfs/58676.pdf, accessed 23 December 2016. 
Figure 1. Disaggregating a technology's experience curve price reduction

Figure 2. LBNL Direct Cost Model, 1kW CHP system [75]. Overall system cost is dominated by balance of plant costs above an annual production volume of several hundred units per year. Note that this cost does not include corporate markups (e.g., sales and marketing and profit margin) and installation costs.

Figure 3. Observed cost reduction for Japan micro-CHP system cost from 2005-2015 with a learning rate of $18 \%$.

Figure 4. Reported costs of fuel cell total system cost per kW for the California SGIP program for (a) SOFC electric power systems, and (b) PAFC, and MCFC CHP systems.

Table 1. Japan's Micro-CHP program and the California SGIP

Table 2. Summary of experience curve learning rates for stationary fuel cells considered in this work

Table 3. Summary of cost reduction disaggregation in fuel cell micro-CHP in Japan from 2009-2014.

Table 4. Summary of incentives for fuel cell micro-CHP in Japan and SOFC fuel cell systems in California under the SGIP program. 